\title{
A HERMENEUTICAL ANALYSIS ON FATWA OF THE COUNCIL OF INDONESIAN ULAMA DEALING WITH DISCRIMINATING SHIA IN INDONESIA
}

\author{
Mukhsin Achmad \\ Postgraduate program of UIN Sunan Kalijaga, Yogyakarta \\ Jl. Laksda Adisucipto, Kabupaten Sleman, Daerah Istimewa Yogyakarta \\ E-mail: mukhsin.achmad78@gmail.com
}

\begin{abstract}
A Hermeneutical Analysis on Fatwa of the Council of Indonesian Ulama Dealing with Discriminating Shia in Indonesia. The present article is aimed at analyzing the Council of Indonesian Ulama (MUI, Majelis Ulama Indonesia) fatwa on Shia in Indonesia. The decree of MUI fatwa should be described and analyzed due to potential powerful to influence Indonesian Muslim community. Besides, there are three dialectics of discovering the fatwa such as the author, the content, and the reader of fatwa. The effect of such decree tends to occur a violence among religious minority such as discrimination and intimidation. The process of producing fatwa does not properly consider five contingencies as the parameter of authoritative fatwa. According to MUI, Shia is one of the deviate belief systems in Indonesia because it has primary different doctrine from ten indicators. To avoid the authoritarianism of fatwa and violence against religious minority, MUI as an official institution who produces the fatwa should consider the five contingencies, namely honesty, diligence, reasonableness, comprehensiveness, and self restraint.
\end{abstract}

Keywords: fatwa; discriminating; minority.

\begin{abstract}
Abstrak: Analisis Hermeneutik terhadap Fatwa Majelis Ulama Indonesia tentang Diskriminasi Syiah di Indonesia. Artikel ini bertujuan untuk membahas fatwa Majelis Ulama Indonesia (MUI) tentang Syiah di Indonesia. Keputusan fatwa MUI perlu dibahas dan dianalisis karena fatwa tersebut mempunya potensi kuat mempengaruhi komunitas Muslim di Indonesia. Selain itu, terdapat perbedaan pendapat di antara tiga dialektika dalam merumuskan fatwa, yakni pengarang, isi, dan pembaca fatwa. Akibat keputusan fatwa MUI itu juga terjadi berbagai bentuk kekerasan terhadap kalangan minoritas agama seperti diskriminasi dan intimidasi. Proses lahirnya fatwa tidak mempertimbangkan lima hal sebagai parameter otoritatif. Menurut MUI, Syiah adalah salah satu kepercayaan yang menyimpang di Indonesia karena Syiah memiliki doktrin yang berbeda dari sepuluh indikator yang ditetapkan oleh MUI. Kecenderungan produksi fatwa MUI tersebut dapat memicu bentuk-bentuk diskriminasi terhadap syiah sebagai kelompok minoritas. Untuk menghindari otoritarianisme fatwa dan kekerasan terhadap minoritas agama, MUI sebagai lembaga resmi yang menghasilkan fatwa harus mempertimbangkan lima parameter, yaitu kejujuran, kesungguhan, masuk akal, menyeluruh, dan menahan diri.
\end{abstract}

Kata kunci: fatwa; diskriminasi; minoritas.

\section{Introduction}

This paper deals with fatwa of Majelis Ulama Indonesia (MUI, the Council of Indonesian Ulama) on Shia in Indonesia. Fatwa of Majelis Ulama Indonesia was chosen because it represents Islamic organizations in Indonesia such as Nahdhatul Ulama, Muhammadiyah, and Persatuan Islam (Islamic Union). ${ }^{1}$ The MUI fatwa

${ }^{1}$ Many actions and demonstrations in Indonesian Muslim society exist for defending the MUI's fatwa like GNPF (Gerakan Nasional Pengawal Fatwa) including the action of 212 and 122 also has strong legitimate position toward its entire society. ${ }^{2}$ MUI is a semi-governmental organization in Indonesia of which aim is to give

and other action. Those tend to show the strong influence and potentially would be corrupted by political interest. MB. Hooker explores it on his book Indonesian Islam Social Change Through Contemporary Fatawa, Honolulu: University of Hawai, 2003, viii at the preface. The same issue will be a latent issue in Indonesia through the different trigger of movement in Indonesia.

2 Zaitun Abdullah and Indra Jaya, Problem Keadilan Bermadzhab di Indonesia, (Jakarta: Lentera Hukum Indonesia, 2014), p. 27. 
advice and fatwa regarding to religious problems in particular, and the nation's problem in general, to the government and society. ${ }^{3}$

Fatwa is an official order of decision on various contexts of Islamic legal discourse ${ }^{4}$ given by a Muslim scholar as a response to a question. ${ }^{5}$ Since being issued, a fatwa could be authoritarian and authoritative ${ }^{6}$ at the same time. The phenomenon of its authoritarian can occur in all aspects including on fatwa discourse in Indonesia.? Three important aspects including fatwa, the mufti (ulama who produces fatwa), and people who interpret the fatwa are connected to each other.

The recent problem of religious understanding has many different interpretations with one another based on their contexts of social and political background. ${ }^{8}$ However, the main problem

3 The council was founded by the Indonesian government on 26 July 1975 when Professor Mukti Ali acted as Minister of Religious Affairs. It consisted of ulama (Muslim scholars) from the Indonesian Army and ulama from all Indonesian Islamic organizations except from the Indonesian Muslim Missionary Council or Dewan Dakwah Islam Indonesia (DDII, founded by Muhammad Natsir, the former president of Masjumi Party). For further description, see Samsul Hadi, Indonesian Council of Ulama, Indonesia Circle. School of Oriental \& African Studies. Newsletter, IC No. 50, Nov 89. See also M. Atho' Mudzhar, Fatwas of the Council of Indonesia Ulama: A Study of Islamic Legal Thought in Indonesia 1075-1988, (Jakarta: INIS, 1993), p. 54.

${ }^{4}$ Norman Fairclough said that "discourse is shaped by relations of power and ideologies, and the constructive effects discourse has upon social identities, social relations and systems of knowledge and belief, neither of which is normally apparent to discourse participants." See Norman Fairclough, Discourse and Social Change, (Cambridge, Polity Press, 1992), p. 12.

${ }^{5}$ A fatwa is a non-legally binding decree. For further explanation please read Robert Pringle, Understanding Islam in Indonesia Politics and Diversity, (Singapore:University of Hawai, 2010), p. 137.

${ }^{6}$ Khaled Abou el Fadl on his preface in Speaking In God's Name: Islamic Law, Authority and Women (Oxford: One World Publications, 2003). Read at the introduction of Amin Abdullah, Pendekatan Hermeneutik Dalam Studi Fatwa Fatwa Keagamaan: Proses Negosiasi Komunitas Pencari Makna Teks, Pengarang Dan Pembaca," a preface for the translation of Fadl's book, Speaking In God's Name.., translated by R Cecep Lukman Hakim (Jakarta: Serambi, 2004), p. viii.

7 Lutfi Assyaukani mentions clearly that there is a strong connection between fatwa and violence in Indonesia. Although the report is about Ahmadiyya, it can be applied to other minority groups as well. Further explanation, see Lutfi Assyaukani, "Fatwa and violence in Indonesia", Journal of Religion and Society, Volume 11, 2009.

${ }^{8}$ Khaled Abou El Fadl and Majlis Ugama Islam Singapura, Islamic Law and Muslim Minorities: The Juristic Discourse on Muslim Minorities from 8th to 17th Century Muis Occasional Papers Series (Singapore: Majlis Ugama Islam Singapura, 2006). is the interpreters become an authoritarian when placing their sole interpretation as the only right one under behalf of God. ${ }^{9}$ It is different from authoritative interpretation which tries to interpret ideal meaning with an appropriate approach and adequate discipline based on the context and social phenomena. The impact of the authoritative interpretation is closed for many possibilities of understanding from any other kind of interpretation because they will be God's representation for understanding the text. ${ }^{10}$

Abou el Fadl distinguishes between authoritative and authoritarian on fatwa. He refers both terminologies for differing "coercive authority" and "persuasive authority". " The first tends to drive another people using influence, gaining a benefit, judging or attacking. Thus, people will reasonably follow without any other choice. The second is ability to drive people's belief based on the trust.

MUI which was founded in 1975 and initiated by President Soeharto has a function as a kind of interface between the government and the Muslim community in the national level. MUI has Fatwa Commission which has special mandate to social responses and religious problems. Fatwa against religious minorities is an important issue to be addressed because it tends to be authoritarian and authoritative at the same time. The logic of protection comes from the majority to the minority. On the contrary, fatwa often becomes a tool of discriminating the minority. Much violences against religious minorities in Indonesian people still happen because of misinterpretation of the context of the fatwa. ${ }^{12}$ ।

9 One example is the case of Basuki Tjahaja Purnama (Ahok) whose speech at Kepulauan Seribu cites Surah al Maidah verse 5 triggers bigger reaction from Muslims who relies their action upon MUI fatwa on blasphemy.

${ }^{10}$ Khaled Abou el Fadl, ...., p., 21. On this phenomenon, Khaled Abou el Fadl uses term "authoritarianism" that is different with the authoritative interpretation.

${ }^{11}$ Abou al Fadl, at the introduction of his book. Fadl borrows the term "coercive" and "persuasive" from Friedman's concept. On his statement, he agrees with Friedman's concept that absolute authoritativeness will often involve an unqualified surrender of judgment.

${ }_{12}$ There is strong connection between MUl's fatwas and violence. See Luthfi Assyaukanie, "Fatwa and Violence in 
examine this phenomenon for some reasons. First, they have a powerful to influence Indonesian Muslim community. Second, there are three dialectics of discovering the fatwas such as the author, the content of fatwa, and the reader of fatwa. Third, violence among religious minorities ${ }^{13}$ such as discrimination, intimidation, and violence is increasing. I utilize hermeneutical authoritative approach of Khalid Abou el Fadl on the fatwa on Shia in Indonesia. ${ }^{14}$

The fatwa on Shia was issued on March 1984 but there is another fatwa about mut'ah that becomes one of Shia jurisprudence. ${ }^{15}$ I examine religious fatwa on Shia be cause as minority, they always become object of discrimination and violence. As minority, they also become vulnerable group of some violence. ${ }^{16}$

According to Setara Institute which monitors religious freedom in Indonesia, there were 216 cases of violent attacks on minority religion in 2010, 244 cases in 2011, and 264 cases in 2012. ${ }^{17}$ Laws are made by state in some countries to protect the minority religion. The majority in academic term refers to power differences among groups rather than the varieties in population size among groups. ${ }^{18}$ Will Kymlicka argues that minorities should be categorized according to two relationships such as (1) minority of the indigenous population and (2) minority of the

Indonesia," Journal of Religion and Society, Vol. 11, 2009, p. 15.

${ }_{13}$ Minority in this term indicates a smaller number in relation to a greater number. Al-Alwani said that the term does not refer to number but power. The community that controls legislation should be described here as the majority, even if it is smaller in number. See Taha Jabir al-Alwani, Towards A Fiqh for Minorities: Some Basic Reflection, London, IIIT, 2003, p. viii at the introduction of M.A. Zaki Baidawi.

${ }^{14}$ Critical discourse analysis is used in this research at three levels. The first level is the production of fatwa, the second level is the distribution of Fatwa and the third level is the consumption of Fatwa. For further explanation please see Norman Fairclough, Discourse and Social Change, p. 80.

${ }^{15}$ Hijrah Saputro (ed), Himpunan Fatwa MUI Sejak 1975, Jakarta: Penerbit Erlangga, 2011, p. 46 and 375 about mut'ah marriage.

${ }^{16}$ Richard T. Schaefer, ed., Encyclopedia of Race, Ethnicity, and Society (Los Angeles and London: SAGE Publications, Inc., 2008), p. 1139.

17 Setara Institute, "Reports on Freedom of Religion and Belief 2007-2009” April 2, 2010, http://www.setara-institute.org/ en/content/report-freedom-religion-and-belief-2007-2009

18 Barzilai, Gad, Communities and Law: Politics and Cultures of Legal Identities, University of Michigan Press, 2003 immigrant community. ${ }^{19}$

I utilize hermeneutical theory of Khalid Abou el Fadl because he introduces three contexts of understanding. The first is the context of textual revelation (Alquran and Sunna) and fatwa. The second is the context of author concerning on the Quran, Sunna, and Fatwa. The third is the context of readers who are Muslim society in general including a layman. Those contexts will have a potential to abuse of power if the author claims that his understanding represented in God's name.

To capture those problems in detail, the major questions to be answered are how do the backgrounds, processes, and procedures of MUI produce fatwa on Shia as a Muslim minority? Does the fatwa tend to be authoritarian or authoritative on Shia? And to what extent does MUI's fatwa on Shia have impact on their relationship towards others?

\section{MUI's Fatwa on Academic Debate}

One of the scholars focused on MUI's fatwa is Atho Mudzhar. ${ }^{20}$ His study focused on fatwa and its relationship to the supportive policy of government during President Soeharto era. The fatwa opposed to government in other side. In addition, M.B. Hooker describes a large number of fatwas from various organizations based on general themes such as ritual practice, the position of women, and medical issues. ${ }^{21}$

On the context of freedom and religious harmony, Syafiq Hasyim also highlighted MUI's fatwas and religious pluralism. He wrote an article untitled "Majelis Ulama Indonesia and Pluralism in Indonesia" and concluded the importance of Indonesia's government for protecting pluralism for maintaining the diversity of cultures and religions. In his opinion, MUI's

\footnotetext{
${ }^{19}$ Said Fares Hassan, Fiqh al- Aqaliyyat, History, Development and Progress, (New York : Palgrave Mac Millan, 2013), p. 12

20 Mohammad Atho' Mudzhar, Fatwa- Fatwa Majelis Ulama Indonesia Sebuah Studi Tentang Pemikiran Hukum Islam di Indonesia 1975- 1988, translated into English as "Fatwas of The council of Indonesian Ulama: A Study of Islamic Legal Thought in Indonesia 1975-1988."

${ }^{21}$ MB. Hooker, Indonesian Islam Social Change Through Contemporary Fatawa, (Honolulu: University of Hawai, 2003)
} 
fatwas are contra-productive for protecting religious pluralism in Indonesia. Syafiq deals with fatwas on pluralism in Indonesia, but he did not pay attention to religious minority in Indonesia. ${ }^{22}$ The interesting thought of his idea is fatwa to solve the problem, but produced another new problem.

Another scholar is Lutfi Assyaukani who paid attention on the fatwa and the violent. ${ }^{23}$ According to him, there is strong connection between fatwa and religious intolerant in Indonesia. The fatwa considered Shia as a dangerous sect because its teachings counter the fundamental doctrines of Sunni. Based on the differences, the MUI "appealed the Sunni Muslims to increase their alert against any possibility of the Shiite influence." Lutfi addressed the strong connection between fatwa and violence in general with religious minority but not only focus on Shia as a subject of his research.

Robitul Firdaus-who concerns on relation between fatwa and violence in Indonesia on his dissertation under the title "Fatawa on Syi'ism in Indonesia (1920- 2012)"-stated that fatwa is not the single aspect of violence. There are many aspects of violence on religious minority such as political and sociological aspect that occured before the fatwa. ${ }^{24}$ On his research, MUI fatwa just becomes one variable among other fatwas from mass organization such as NU and Muhammadiyah.

Another issue of Shia as a minority group, Chiara Formichi wrote on her article entitled "Violence, Sectarianism, and the Politics of Religion: Articulations of Anti-Shia Discourses in Indonesia" said that Anti-Shia opposition in Indonesia has existed for many decades. However, physical violence started with an isolated event in 2000 , followed by an eruption of violence

\footnotetext{
${ }^{22}$ Syafiq Hasyim, "Majelis Ulama Indonesia and Pluralism in Indonesia, Philosophy and Social Criticism” 2015, Vol. 41(4-5), pp. 487-495.

23 Lutfi Asyaukani, "Fatwa and violence in Indonesia", Journal of Religion and Society, Volume 11 (2009) p. 1

24 Robitul Firdaus, Fatawa on Shi'ism in Indonesia (19202012)A Critical Analysis, (Malaysia, A Dissertation of Doctoral degree on IIUM, 2016)
}

in 2006-2013. Besides the heightening of antiAhmadiyyah voices, the sharpening Sunni-Shia dichotomy can be seen as a reaction to the outing of Islam from power with the appointment of Megawati Soekarnoputri as president of the Republic Indonesia in 2001.25

Zulkifli on his dissertation investigated the struggle of Shia. ${ }^{26} \mathrm{He}$ highlighted the rejection of Shia related to the Shia doctrine on mut'ah and the Shia popularity among young Muslims in collage. On his opinion, MUI issued the fatwa on Shia based on some reasons. First, MUI stated that the fatwa responded to what it is considered to be a growth in the practice of mut'ah among Muslims in Indonesia, and in particular among youths and students. Second, according to MUI, there had been anxiety among parents, 'ulama, leaders, educators and the wider Muslim community that the practice of mut'ah was being used as Shia's propagation act in Indonesia. Third, MUI affirmed that the majority of Muslims in Indonesia are Sunnis who reject Shia in general and its teaching of mut'ah in particular.

Moch. Nur Ichwan said that MUI was initiatively President Suharto's idea and it regarded as a quasi-official speaker of the State Palace. ${ }^{27}$ Ichwan noted that MUI has given many recommendations affirming state policy in the social and religious fields, but he urged that a comprehensive reading of MUI and its declarations are required. He also showed that during "Reformation Era" (a period after Suharto's fall in May 1998), MUI attempted to play a more proactive role in the political arena. Nevertheless, as an avowedly non-political institution, MUI proposed "moral" reform as the core solution to the crisis that the country has faced since 1997. MUI did not engage in

${ }^{25}$ Chiara Formichi, Violence, Sectarianism, and the Politics of Religion: Articulations of Anti-Shi'a Discourses in Indonesia, Published by: Southeast Asia Program Publications at Cornell University Stable URL: http://www.jstor.org/stable/10.5728/ indonesia.98.0001

${ }^{26}$ Zulkifli, The Struggle of Shi'ism in Indonesia (Australia: ANU Press, 2013), pp. 10-11.

${ }^{27}$ Moch. Nur Ichwan, "Ulama, State and Politic: Majelis Ulama Indonesia After Suharto", Journal of Islamic Law and Society, Vol. 12 No. 1, Fatwas in Indonesia, pp. 45-72. 
politics, however, and Ichwan analyzed its political activities during the administrations of Suharto's successors, B.J. Habibie (May 1998 - October 1999) and Abdurrahman Wahid (October 1999 -July 2001). Examining on what he called MUI's "discursive products", he showed that these products ranged from silence to an apparently hierarchical of "opinions," pieces of "advice," and eventually "fatwa." 28

Although there are a lot of previous researches studying fatwas especially on MUI fatwa, they do not use hermeneutical negotiate of Abou el Fadl on the fatwas against religious minority, especially the discrimination against Shia in Indonesian society. This research, therefore, has strong legitimate to investigate the problem of fatwa and religious minority especially on Shia using hermeneutical theory of Khalid Abou el Fadl. This paper would like to ask whether fatwa is more authoritative, to examine its impact on religious minority, and to find out the relationship of religious harmony in Indonesia.

\section{Discriminating Shia in Indonesia}

According to Indonesian regulation 1999 number 39 (Constitution Number 39 Year 1999) article 3 of verse 1 , discrimination is a limitation of action, harassment, expulsion/banishment directly or indirectly based on human difference from religion, ethnicity, economic group, and politic. School of religious thought also can impact on decrease from rights, social legitimacy, and deviation individually or collectively.

Shia is one of the minority Muslims in Indonesia. The terminology of minority group could be defined by the community recognized based on different racial, religion, ethnicity and those who lose their rights because of prejudice and discrimination. The discrimination occurs because of imbalance perception and action

${ }^{28}$ On this Issue Nico JG Captein quoted Moch Nur Ichwan about the MUI's fatwas in the New Order era. See more about the article of Nico J.G. Kaptein, "Fatwas In Indonesia, Islamic Law and Society,"Vol. 12, No. 1, Fatwās in Indonesia (2005), pp. 1-8. among society ${ }^{29}$ Shia is minority ${ }^{30}$ because it is smaller than Sunni in accordance with majority, number of membership, political power, and social action.

The discrimination against Shia commonly appears on two levels, namely (1) sociological judgment and (2) theological judgment. MUI fatwa is included on this level. Previously just a legal opinion from jurist, fatwa transforms to legally binding such as positive law for justifying the violence and discrimination.

Fatwa of MUI actually has potential to become a theological judgment. This article capture on two fatwa(s) addressed in national level and in local level in Sampang. The first fatwa was issued in March 1984, while the MUI fatwa in Sampang regency and East Java Province were issued in January 2012. The fatwa of MUI in national level is different from the fatwa in Sampang and East Java Province. National fatwa stated only the appeal and recommendation to all muslim people to wary the wide spreading of Shia in Indonesia because the Shi'a has the primary differences from Sunni majority.

The primary differences are shown that Shia rejects prophet tradition (hadits) which is not transmitted by ahl bait, while ahlus sunnah wal jama'ah does not differ that based on 'ilm mustalah hadith. Shia argues that "a leader (Imam) must be a holy man (ma'sum), while ahlus sunnah wal jama'ah argues that the Imam is somone who has a potential on wrong conduct. The In addition, Shia does not recognize the consensus (ijma') without involving "Imam", but ahlus sunnah wal jama'ah recognizes it without requiring and involving "Imam". They also argue that conducting the imamah in the government is one of the pillars of Islam, but Sunni argues that the goal of imamah is to protect Islamic teaching

${ }^{29}$ George A. Theodorson and Achilles G. Theodorson, A Modern Dictionary of Sociology: The Concepts and Terminology of Sociology and Related Disciplines (New York: Barnes and Noble Book, 1979), 258-259.

30 The number of Shi'a is about 3 million followers in Indonesia. They choose to be silent minority for safety. See Zaitun Abdilah and Indra Wijaya, Problem Keadilan Bermadzhab Indonesia, (Jakarta: Lentera Hukum Indonesia), 8 
and umma's interests. Finally, they commonly do not accept the leadership of Abu Bakar shiddiq, Umar bin Khattab, and Usman bin Affan, while ahlus sunnah wal jama'ah acknowledge such four caliphs.

Based on the considerations above especially the difference of "imamah", MUI appeals to all Muslim in Indonesia who have ideology of ahlus sunnah wal jama'ah to increase the wary many possibilities of of Shia ideology infiltration." ${ }^{31}$ The fatwa of MUI Sampang regency differ with the fatwa in national level on its redaction. The primary different fatwa is not on the term of Shia but the doctrine spread by Tajul Muluk is deviant. The reason of using this term is to localize the issue in order not to wide spreading in other region. This fatwa addressed on personal not on shi'a as community. Meanwhile, the fatwa of East java province decreed that (1) to strengthen and regulate the decisions of MUI at the local district that Shia (especially Imamiyyah itsna asyariyah or using the initial name of ahl bait) is deviant and mislead. Proclaming the use of ahl bait term for the follower of Shia is the hijack of Prophet Muhammad descent (ahlu al-bait).

MUI recommended to Muslim people to be aware of Shia ideology's influence (especially Shia itsna asy'ariyah) because it is contraproductive with Islamic teaching which gives them a good life. In addition, the national and local government should not give an opportunity to Shia ideology to spread its edology in Indonesia due to majority of Indonesian people is ahlus sunnah wal jama'ah. Thus, the engagement of Shia ideology tends to potentially become disintegration of Indonesian Republic. The national and local government should apply some actions through the regulation such as prohibition Shia activity and strengthen a strong action in handling the existing conflict. Its intervention is not only addressing on various events but also on overcoming the conflict,

${ }^{31}$ See Hijrah Saputra et.al. (eds), Himpunan Fatwa Majelis Ulama Indonesia sejak 1975, (Jakarta: PT Erlangga, 2011),46. For examining other fatwa about Shi'a which is about mut'ah marriage, the MUI fatwa on mut'ah was emerged in 1997. This fatwa resembles more Islamic jurisprudence rather than theological aspect. terrorism, and comprehensive treatment for violence. The goverment also should make a clear action in handling the deviation ideology. Finally, the chairman of the Council of Indonesian Ulama has a responsible for strengthen the fatwa deals with the deviation of Shia's doctrine. Thus, the fatwa should be decreed nationally. ${ }^{32}$

Each fatwa rejected Shia's ideology by using differences language. The fatwa in national level is emerged earlier uses soft terminology on rejecting the Shia through using the term "to wary the widespread of Shia", while the fatwa in Sampang used the Fatwa against the doctrine spread by Tajul Muluk. This fatwa will localize the problem only on the personal level. The fatwa of east Java Province emerged later that uses strong and direct term "Shia is a deviate ideology". In national level, the first fatwa excludes prohibition for violence and discrimination against Shia but such fatwa also prohibit conducting violence as well as prevent the conflict among Muslim society. The early fatwa recommended Muslim people to increase awareness on widespread ideology of Shia while the later fatwa is to prohibit judgment.

The purpose of both fatwa is actually to protect ideology owned by the majority and to treat minority equally. In fact, the fatwa(s) likely played role as a justification for violence against shia community especially in Sampang because the fatwa gave a recommendation to the local government to issue the governmental policy to manage and regulate the spreading of Shia's ideology among people. This phenomenon potentially becomes authoritarian of the majority that steps down the minority. The authoritarian tends to effect the discrimination in many aspects of life. Although the fatwa is no single trigger of violence, it emerges other factors of discrepancy such as economic, politic, and social jealousy in Sampang.

In December of 2011, the discrimination and violence occurred in the East Java especially in Sampang such as attack and fire-raising. In May

${ }^{32}$ The quotation from MUI Fatwa 2012 of East Java, No: Kep-01/SKF-MUI/JTM/I/2012 about the deviant Shi'a. 
2012, there was a conflict because of different interpretation of Islamic teaching between Shia and other common Muslim societies in Jember, East Java. Furthermore, in August 2012, hundreds of people attacked Shia community in Sampang, Madura. ${ }^{33}$ It was said that the discrimination against Muslim minority still occures. ${ }^{34}$ Seeing this phenomenon, Frans Magnis Suzeno further highlighted that religious minority is more potential to become victim of violence. For instance, many people under the Susilo Bambang Yudhoyono goverment, the sixth president, were expelled from their home so they become unhappy in their new place. ${ }^{35}$

Therefore, religious minority on this paper not only refers to the quantity (greater or smaller) but also refers to the quality described as power. ${ }^{36}$ The hegemony of majority toward minority in different religion or same religion with different schools (Sunni-Shia) considerably comes from the power. The main issue of the minority is that access of the power such as the rights of politics, economy, and social is still status of imbalance. ${ }^{37}$ The unballanced relation makes an impact to the phenomenon of authoritarianism including on the fatwas.

The phenomenon of authoritarianism and despotism against Shia in Sampang Madura, East Java is a manifestation of power which produces the knowledge in the contestation between

33 Compare with the paper of Robitul Firdaus, "Paham dan Gerakan Syi'ah di Indonesia" (paper on Islamic Studies Forum for Indonesia (ISFI), 21 December 2012, in International Islamic University Malaysia (IIUM) Gombak, Selangor),11. See also "Polri Dianggap Lalai pada Kasus Sampang," URL: http:// www.suarapembaruan.com/home/polri- dianggap-lalai-padakasus-sampang/23898 dan "Tentara Dekati Ulama Cegah Kasus Sampang Terjadi di Jabar,” URL: http://www.suarapembaruan. com/home/tentara-dekati-ulama-cegah-kasus-sampang-terjadi-dijabar/23935

34 "Bupati: Relokasi Warga Shi'a ke luar Madura Realistis," http://www.bbc.co.uk/indonesia/berita_indonesia/2013/05/130508_ Shi'a_sampang.shtml accessed on 13 June 2013. See also "Relokasi Kelompok Minoritas Tidak Tepat," http://www.bbc.co.uk/indonesia/ berita_indonesia/2012/10/121024_hakminoritas.shtml and Wayan Agus Purnomo, "Shi'a Sampang Mengadu ke DPR Menolak Relokasi,"

35 Zaitun Abdilah and Indra Wijaya, , 9.

36 Taha Jabir al Alwani.

37 Dennis Toombs, Power: Why We Want It and What To Do with It, (Promotheus Books, 2016), 85. On this book Toombs explores human behavior in terms of power in all manifestations across a wide spectrum. He examines the subtle dynamics of power in interpersonal relationship. religion and politics and between politician and religious leader in the local context. Although the MUl's fatwa in East Java emerges later than the violence against Shia in Sampang, I argue that MUl's fatwa of East Java plays an important role in permitting and justifying the violence.

The other problem of the religious minority is the psychology aspect such as the feeling of becoming a minority within a society. The violence against minority especially in the Shia case such as intimidation, judgment of deviation, despotism, discrimination, is the example of the violent. In this sense, the psychology of minority should become primary consideration to produce the fatwa. A fatwa without considering the psychology aspect is injustice condition and thus contradicts the doctrine of religion.

The first factor of discrimination that againsts $\mathrm{Shia}^{38}$ is faith. This factor emerges from the difference of theology and Islamic jurisprudence. It sets up the unconsciousness for Muslim in majority by stereotyping and prejudicing Shia, for instance deviant or lost a way. Therefore, it is understandable for MUI to produce the fatwa to protect the belief system among Muslims in which Sunni becomes the majority. The second factor is politics. In Indonesia, the political factor of historical background of MUI became evident for issuing fatwa against Shia in 1984 when its main argument was for creating political stability. The fatwa stated that "Shia argues that strengthening leadership/government (imamah) is the essential principle of religion, while Sunni argues that-for the public interest as point of view-using leadership of government is for implementing Islamic teaching." Furthermore, Shia had targets for imamah/the leadership of government based on their thought. MUI issued fatwa by suggesting Muslim community especially Sunni as a majority to wary many possibilities from Shia doctrine." The third is Economical factor. This factor emerged on the case of Shia in Sampang, Madura. A contestation among religious leaders occurred because of the celebration of

${ }^{38}$ Zaitun Abdilah and Indra Wijaya, p, 27-29 
Prophet Muhammad's birth (maulid) by inviting local cleric (Kyai). People would offer help and pay the kyai for every celebration of maulid. Thus, poor people who did not have enough money said that following Muhammadiyah or Shia is better than those who were paying some money expensively for this celebration. The fourth factor is social gap. Like economic factor, this factor emerged in Sampang due to contestation among religious local leaders in Sampang. Social jealousy created discrimination against Shia as a minority. Violence against Shia in Sampang occurred because of social jealousy from local religious leader vis a vis Shia religious leader in Sampang.

On the case of MUI fatwa on Shia as a deviate, at least there are eight despotisms occur, namely (1) criminalization, (2) feeling under pressure, (3) attack and destroying, (4) forced-movement to other place, (5) separation, 6) intimidation and terror, (7) no protection from apparatus, and (8) the discriminalitation of civil rights. All of them are different situation experienced by some people in any places based on escalation of the conflict.

\section{Hermeneutical Analysis: A View from Khalid Abou el Fadl}

I utilize hermeneutic of Khalid Abou el Fadl to analyze the MUl's fatwa on Shia. Khalid Abou el Fadl39 is a Muslim scholar who concerns on hermeneutical analysis, even though he does not

${ }^{39}$ Khaled Abou El Fadl is one of the most prominent and influential Islamic thinkers in the modern age. An accomplished Islamic jurist and scholar, he is Professor of Law at the UCLA School of Law where he teaches Islamic law, Immigration, Human Rights, International and National Security Law. Fadl previously taught Islamic law at the University of Texas at Austin Law School, Yale Law School and Princeton University. He holds degrees from Yale University (B.A.), University of Pennsylvania Law School (J.D.) and Princeton University (M.A./ Ph.D.). He is one of the world's leading authorities on Islamic law, and a prominent scholar in the field of human rights. teaches International Human Rights, Islamic Jurisprudence, National Security Law, Law and Terrorism, Islam and Human Rights, Political Asylum and Political Crimes and Legal Systems. $\mathrm{He}$ is also the Chair of the Islamic Studies Inter-departmental Program at UCLA. Among his honors and distinctions, Fadl was awarded the University of Oslo Human Rights Award, the Leo and Lis Eitinger Prize in 2007, and named a Carnegie Scholar in Islamic Law in 2005 mention hermeneutic theory explicitly, but the frame of thought on his book under the title "Speaking in God's Name" is so hermeneutic. ${ }^{40}$ Discourse on fatwas deals with a lot of matters like exegesis, theological doctrines, eschatology, heresy, history, Sufism practices, political matters, public morality, etiquette, and manners. Fatwa is structurally connected with istifta although it may not always be the answer to a question. Fatwas are not produced in the vacuum sphere but they have many backgrounds behind them.

I use Abou el Fadl thoughts that concerning on the authoritative hermeneutical for the negotiation of three elements between the word of author, reader, and text to address the problems dynamically. He proposed many balanced approach when engaging in the task of interpreting texts such as the Quran in which neither the author's intent nor the reader have the upper hand in determining its meaning. It is the balance between these three pillars. According to Fadl, the hermeneutical authoritative is balancing and negotiating the text of the content of fatwa, the author, and the reader. More than negotiating and authoritative, he desired to measure product of Islamic thought including fatwa with the five contingencies; honesty, reasonableness, diligence, comprehensiveness, and self-restraint.

He also argued that authoritarianism trends could be prevented with five contingencies to create a trusted authority. The first is honesty ${ }^{41}$ that offers expectation to someone who has an objective attitude to their understanding. It means that someone understands something based on the fact, than he does not want to corrupt his/ her understanding. The second is dilligence. ${ }^{42}$ This attitude is supposed that someone can create an effort optimally by inquiry and understand something by verifying the problem with text and coherent relation between one and another

$4^{40}$ Khaled Abou al Fadl, Speaking In God's Name Islamic Law, Authority and Women (Oxford: One World Publications, 2003)

${ }^{41}$ Khaled Abou al Fadl, Speaking In God's..., p.54

${ }^{42}$ Khaled Abou al Fadl, Speaking In God's..., p. 60 
text. The third is comprehensiveness. This pillar is deemed that someone tries to analyze using all of relevant considerations to the text addressing the problem. The fourth is reasonableness. This pillar is assumed that someone interprets text rationally. This standard is abstract but according to Fadl the truth is correct in common. ${ }^{43}$ The fifth is Self- restraint. This attitude tends to be self-control and pre-condition for anticipating despotism and disobedience from the reader. In order to exercise the necessary of self-restraint, the agent would have to take Qur'anic verses into his/her heart. ${ }^{44}$

Using Fadl's view, field triangulation (of text, of author and of reader) is useful to analyze MUI's fatwa. Text is revealed by God in Arabic language. MUI Commission of Fatwa interprets the text based on their own understanding and socio-political background. All of the MUI's members are Sunni from different mass organization such as NU, Muhammadiyyah, Al Washliyyah, and Persis. Looking at the political context, there is tension between Sunni and Shia. As a minority in Indonesia, Shia becomes vulnerable group and receives various violent from majority.

\section{Negotiate Hermeneutic on MUI Fatwa against Shia}

Abou el Fadl suggested that the interpretation of text should emerge from the interaction of author, text, and reader which creates a balancing and negotiating process between those three, and no one ought to dominate the determination of meaning. ${ }^{45} \mathrm{He}$ also suggested that the determination of meaning has been delegated to the human agent. In this sense, God has used two mediums: the medium of the text and of human being. The text is expected to shape the attitudes and behaviors of the human agent and there is little doubt that the human agent also shapes the meaning of the text.

Fatwa is the interaction of mufti and the

\footnotetext{
${ }^{43}$ Khaled Abou al Fadl, Speaking In God's..., p. 90

${ }^{44}$ Khaled Abou al Fadl, Speaking In God's..., p.56

${ }^{45}$ Khaled Abou al Fadl, Speaking In God's..., p. 90.
}

text using interpretation. The text is absolute that only God who knows the truth absolutely. MUI through Fatwa Commission is a special agent mandated by government to produce fatwa. In addition, MUI as religious institution should provide solution among Muslim society on the problem but the fatwa often becomes a problem when accepted and consumed by the society. The problem of MUI's fatwa on hermeneutic perspective actually could appear on each level, even on the text of fatwa, in the author or in the reader. To avoid, Fadl offers the requirements of honesty, diligence, selfrestraint, comprehensiveness and reasonableness. He said that respecting the integrity, the text independence and the absolute autonomy of the Divine means that no interpretive community or individual is able to be forever close to the possibility of re-engaging and re-examining text or divine will. ${ }^{46}$

There are many problems with the Muslim minority including Shia in many levels such as the level of text, the level of author and the level of reader. In other side, discriminating on Shia also happens in the context of human rights, psycho-social right and freedom of fear. On the level of reader or society, there are ten indicators of deviate identity from Islamic belief system according to MUI, namely (1) rejecting the six pillars of faith and the five pillars of Islam (2) believing and/or following a belief ('aqidah) incompatible with Sharia, (3) believing in revelation (wahy) after Quran, (4) rejecting the authenticity and/or the truth of the contents of the Quran, (5) interpreting the Quran without relying it on the (correct) principles of interpretation, (6) rejecting the prophetic tradition (Hadith) as a source of Islamic teachings, (7) disrespecting, disgracing and/or downgrading the Prophets and Messengers of Allah, (8) rejecting Muhammad as the last Prophet and Messenger, (9) changing the principles of devotion ('ibadah) established by sharia, and (10) charging other Muslims as "unbeliever" (kafir) without proper basis of sharia.

\footnotetext{
${ }^{46}$ Khaled Abou al Fadl, ... p. 132.
} 
Based on those ten indicators, the Shia group is deviate according to MUl's fatwas although the consideration does not only refer to it. Fatwa even on national or local level should consider the prevention principle (dar'ul mafâsid muqaddamun ala jalb al mashâlih). Although religious harmony in Muslim society is the main goal of MUI to make a fatwa, the reality is really different. After fatwa emerged, a lot of religion-based violence still occurs and increases in Indonesia such as the phenomenon of violence against Shia in many regions of Indonesia. In this sense, all of forms of violence against Shia cannot be justified for whatever reasons especially for human rights perspective because every person based on Indonesian Constitution "UUD 1945" passage 29 which guarantees the freedom on choosing religion and the school of belief based on each interest. Thus, the government is obliged to protect the rights the freedom of religion and people's belief. In fact, it is not easy to harmonize between the psychology of majority and the psychology of minority. ${ }^{47}$ Someone who feels adhered to majority sometimes looks arrogant, superior, despotic, powerful, and hegemonic.

MUI and its fatwa are two faces on the same coin. MUI is semi-official government institution representing mass organizations such NU, Muhammadiyyah, and PERSIS that has a mandate to provide fatwas to control and monitor religious life. It also aims to solve the problem among Muslim society although the violence still occurs in the name of fatwa defender. When the fatwa becomes a justification of violence rather than "bayan" function to solve the problem, it tends to be misused and becomes authoritarian. For instance, the fatwa against Shia in East Java after Shia gets violence from other group of society. It was followed that fatwa acts to legitimize previous violence.

${ }^{47}$ The contestation between religion and politics among Muslim still becomes trending topic especially the issue on religious minority, political issue and the conflict of interest. For comparing the result of the researce, see Bahrul Ulum, Ulama dan Politik Nalar Politik Kebangsaan Majelis Ulama Indonesia (MUI) (Yogyakata: Pustaka Pelajar, 2015) pp. 238- 245
Three aspects of hermeneutical analysis according to Khalid Abou el Fadl are the main focus on this issue. The field of author, content of text, and reader is inseparable aspect. MUI which produces the fatwas is the representation of Islamic mass organization in Indonesia. Its product, a fatwa, tends to be authoritarian and authoritative. The reader of fatwa also potentially misinterprets it for justifying the violence against religious minority including Shia in Indonesia.

On the perspective hermeneutical authoritative, MUI's fatwa on Shia tends to be authoritarian because of many reasons. The MUI's fatwa only uses one perspective namely Sunni perspective and it becomes dominant to produce the knowledge of fatwa without deep exploration about the variant of Shia. The mainstream of Islamic thought of MUI is protecting the aqidah ahlussunnah wal jama'ah (sunni) as majority group from the other belief system deemed to be deviant. MUI seems not to crosscheck with the Shia by using dialogue or depth interview in conducting the fatwa. Using the five contingencies of Fadl, MUI is dishonest, non-diligent and incomprehensive because it just uses dominant perspective from Sunni's thought, neglects Shia perspective or does not invite some informants to participate and discuss on the issue.

The mainstream of Sunni ideology produces the knowledge by stereotyping all schools of Shia as deviate. The emergence of apocalyptic understanding in the member of MUI also contributes to the production of fatwa as authoritarianism. The apocalyptic ${ }^{48}$ is the mindset of understanding religious text (revelation) through absolute interpretation. Using the term of Fadl, it is the monopoly of understanding to the text by representing God's name through the fatwa to eliminate the other who has different ideology.

${ }^{48}$ Frances L. Flannery defines apocalyptic as an orientation believing that Divine realm (transcendent) has sent a revelation to a selected few persons, the righteous to disclose divine view through a transformative or meaningful one. See Frances $L$ Flannery, Understanding Apocalyptic Terrorism: Countering The Radical Mindset. (New York: Routledge, 2016), 6. 
The faith-based assumption of Sunni ideology which appears on the member of MUI as the first reader as well as the author of fatwa inspires the product of fatwa to become authoritarian to Shia. Its impact is discrimination on all aspect of lives from mode of thoughts (prejudice, stigmatization) to action such as the freedom to express their belief and to access equality with others.

The recent chairman of MUI, K.H. Ma'ruf Amin said that fatwa about belief addressed for guiding and supervising the ummat including the ideology of Muslim society. ${ }^{49}$ Actually, the function of fatwa is to clearly explain (bayan) some problems. However, the local fatwa of MUI in East Java is misused by the State Court to cast into prison Tajul Muluk for 4 years. In the other word, fatwa sometimes explain the problems but it is used by intolerant people to conduct violence against minority. Therefore, although fatwa is morally not legally binding, it is often adopted by government as if it were legal binding.

Public perception tends to not differ between fatwa as an opinion from Muslim jurist and the court judgment. This condition must be considered by a mufti to deliver the fatwa as a morally binding and "a sacred opinion" that potentially used to marginalize and violate religious minorities. On this case, MUI as an institution has a contribution to despotism against religious minority. Instead of solving the problem, MUI fatwa creates a new problem in Muslim society. Thus, MUI should forbid people to use fatwa as justification for violence against religious minority whatever the reasons. MUI should condemn those who use its fatwa for discriminating or violating religious minority.

The characteristic of fatwa which still happens is between authoritarian and authoritative. Fatwa as a product of Islamic law is the result of Islamic thought from Islamic jurist by compromising and negotiating text (nash), the writer or the author (God), and the reader (Islamic Scholars/Clerics). In this case, there is a contestation between the

49 Republika Newspaper, 08/11/2012 author/writer and the reader in implementing text. The despotism of the reader to the text is difficult to avoid. It happens on two levels, namely (1) despotism of interpreting the meaning of the text and (2) taking over the rights of author. This becomes main problem for ontological Islamic law because Islamic law is the dialectic between reason and revelation; a negotiation between the absolute and the relative. On epistemological perspective, Islamic law is relatively absolute. It is relative because the reason tries to understand the revelation.

To prevent the despotism and authoritarianism, Abou ElFadl promoted the Quranic verse: "wa mâ yallam junûda rabbik illâ huwa, "And none knows the hosts of your Lord but He" (al-Muddaththir [74]:31). This verse, according to him, rejects the people's claim as God's soldiers who took God's authority. Someone could hope and make effort to become the God's soldiers but no one could claim that he/she has God's mandate. According to Abou Fadl, the above verse creates serious tension in the relationship among the text, the reader, and the author.

\section{Conclusion}

Based on investigating data, this research concludes that MUI fatwa is powerful and its legitimation is formidable amid Muslim society especially in the context of social and political interpretation in Indonesia. Meanwhile, MUI fatwa on Shia tends to be authoritarian and results in discrimination against Shia. Since the conflict between Shia and Sunni has existed for long time, it is possible that it influences collective memory of MUI members on issuing a fatwa. The collective memory as I mentioned previously is like the success of Iran revolution and how it influences and inspires young Muslims to follow Shia. MUI reacts and condemns it as contra-productive on supporting religious harmony in Indonesia. I argue that MUI prefers on sad adz-dzariah (preventive methods) by using one side perspective (only Sunni as a majority) for eliminating disharmony of religious life although this choice or decision makes new problem instead to discriminating religious minority especially to Shia. 
Imama of Shia is deemed to be dangerous for Indonesia government for Shia has special doctrine about the government such as Hizbut Tahrir Indonesia (HTI): it can trigger rebellion to Indonesian government. As a semi-government institution, MUI does not consider other perspective and initiates dialogue (including with Shia community) on the process of producing fatwa. MUI should ideally protect the minority from any discrimination and violent as MUI is an umbrella for all Muslims whatever their school of thought and beliefs are. In fact, MUI is more inclined to protect Sunni community as a majority in Indonesia by applying ten parameters to determine other religious belief as deviant or not. Furthermore, the beliefs system which contradict the majority especially on the primary belief (pillars of Iman and Islam) are more prone to be judged as a deviant sect.

Using hermeneutical perspective of Abou el Fadl, MUI fatwa properly ignores five contingencies as the parameter of authoritative fatwa to avoid authoritarianism. On this case, $\mathrm{MUI}$ is incomprehensive for different perspective from other is not considered during the process of issuing fatwa. In the issue of investigating Shia doctrine, MUI absolutely is not diligent because there is no dialogue and exploring all of Shia groups is not primary approach to solve the problem. According to Fadl, those conditions show a coercive approach and tend to authoritarian therefore.

MUI experienced dilemma on the context of Indonesian country. MUI would like to provide solution for religious disharmony in Indonesia while its fatwa becomes new problem especially for Shia which gets discrimination and intimidation. On one side MUI has to answer and give solution for religious problem based on Islamic doctrine but in other side MUI also has to accommodate the democratic value and freedom of human rights including for the rights of minority group. The fatwa of MUI should therefore combine five contingencies and negotiate three worlds of texts, author and reader to avoid discrimination and violence against the minority especially Shia.
To avoid the authoritarianism of fatwa and the violence against religious minority, MUI as an official institution which produces fatwa should consider those five contingencies: honesty, diligence, reasonableness, comprehensiveness and self-restraint. It also needs to consider the sixth contingency, psycho-social aspect because the minority is not only about the problem of power but also the problem of psychology of relationship with the other which is equal and respects each other rights.

\section{References}

Ahnaf, Mohammad Iqbal et.al, Politik Lokal dan Konflik Keagamaan: Pilkada dan Struktur Kesempatan Politik dalam Konflik Keagamaan di Sampang, Bekasi, dan Kupang, Yogyakarta: CRCS UGM, 2015.

Alwani, Taha Jabir, al,- Towards a figh for minorities some basic reflection, London, IIIT, 2003, p. viii at the introduction of M.A. Zaki Baidawi. , Towards a figh for minorities some basic reflection, London, IIIT, 2003

Anwar, Syamsul, Fatwa, "Purification and Dynamization: A Study of Tarjih In Muhammadiyah, Fatwas in Indonesia", Islamic Law and Society,Vol. 12, No. 1, Fatwās in Indonesia , 2005.

Ari Wibowo, Rahmat, "Fatwa MUI Tentang Penyimpangan Ajaran Islam Dan Tindakan Pelanggaran Kebebasan Berkeyakinan" Journal Theosofi: Jurnal Tasawuf dan Pemikiran Islam. Vol. 3, No. June 1, 2013

Asyaukani, Lutfi, "Fatwa and violence in Indonesia", Journal of Religion and Society, Vol. 11, 2009.

Barzilai, Gad, Communities and Law: Politics and Cultures of Legal Identities, University of Michigan Press, 2003.

Bates, T. "Gramsci and the Theory of Hegemony". Journal of the History of Ideas, Vol. 36, No. 2 Apr.-Jun. 1975.

Burhani, Ahmad Najib, "Treating minorities with Fatwas: a study of the Ahmadiyya community in Indonesia", Published online: 23 November 2013 \# Springer Science+Business Media Dordrecht 2013 
Burhanudin, Jajat, "Aspiring For Islamic Reform Southeast Asian Requests for Fatwas in AlManar", on Journal: Islamic Law and Society, Vol. 12 No. 1, Fatwas In Indonesia

Captein, Nico JG , "Fatwas in Indonesia”, Islamic Law and Society, Published by Brill, Vol. 12, No. 1

, “The Voice Of The 'Ulama': Fatwas And Religious Authority In Indonesia", Archives de sciences sociales des religions, Année, No. 125, Authorités Religieuses en Islam, Jan. Mar., 2004

El Fadl, Khaled Abou Speaking In God's Name Islamic Law, Authority and Women Oxford: One World Publications, 2003

El Fadl, Khaled Abou and Majlis Ugama Islam Singapura, Islamic Law and Muslim Minorities: The Juristic Discourse on Muslim Minorities from 8th to 17th Century Muis Occasional Papers Series,Singapore: Majlis Ugama Islam Singapura, 2006.

Fairclough, Norman, Discourse and Social Change,Cambridge, polity Press, 1992

Fatwa MUI Jatim No. Kep-01/SKF-MUI/JTM/I/2012 Tentang Kesesatan Ajaran Shiah

Formichi, Chiara, Violence, Sectarianism, and the Politics of Religion: Articulations of AntiShia Discourses in Indonesia, Published by: Southeast Asia Program Publications at Cornell University Stable URL: http://www. jstor.org/stable/10.5728/indonesia.98.0001

Foucault, Michel, Power/ Knowledge: Selected Interviews and Other Writings, United State of America: Harvester Book, 1980 , The Archeology of Knowledge, New York: Routledge Classic, 2002

Hadi, Samsul, Indonesian Council of Ulama, Indonesia Circle. School of Oriental \& African Studies. Newsletter, IC No. 50, Nov 89

Hasan, Noorhaidi, “Between Transnational Interest and Domestic Politics Understanding Middle Eastern Fatwas on Jihad in the Molucas", Journal: Islamic Law and Society, Vol. 12 No. 1, Fatwas in Indonesia.

Hassan, Said Fares, Fiqh al- Aqaliyyat, History, Development and Progress, New York : Palgrave Mac Millan, 2013.
Hasyim, Syafiq, Majelis Ulama Indonesia and Pluralism in Indonesia, Philosophy and Social Criticism, Vol. 41, 2015.

Hooker, MB. Indonesian Islam Social Change Through Contemporary Fatawa,Honolulu: University of Hawai, 2003.

Ichwan, Moch. Nur, "Ulama State and Politics: MUI after Suharto", Islamic Law and Society, 12.12005 .

Jarjani, Ali bin Muhammad Abu Hasan , al,- AlTa'rifat, the first edition, Beirut: Dar alfikr, No Year

Kaptein, Nico JG, Fatwas in Indonesia, Islamic Law and Society,Vol. 12, No. 1, Fatwās in Indonesia, 2005.

Ma'luf, Louis, al-Munjid fi al lughah, Beirut Syurutuh wa adabah,http;//www.fiqhacademy.org.sa/ qarat/17-2html: Dar al Masyriq, 1977

Mogashoa, Tebogo, "Understanding Critical Discourse Analysis in Qualitative Research" International Journal of Humanities Social Sciences and Education (IJHSSE) Vol. 1, July 2014.

Mudzhar, M. Atho', Fatwas of the council of Indonesia Ulama: A Study of Islamic Legal Thought in Indonesia 1075- 1988, Jakarta: INIS, 1993.

Niam, Asrorun, (editor), Fatwa Majelis Ulama Indonesia Dalam Pandangan Akademisi Peran Fatwa MUI dalam kehidupan Berbangsa dan Bernegara, Jakarta: MUI, 2017.

Pringle, Robert, Understanding Islam in Indonesia Politics and diversity, Singapore:University of hawai, 2010.

Saputra, Hijrah (editor), Himpunan Fatwa Majelis Ulama Indonesia Sejak 1975, Jakarta: Penerbit Erlangga, 2011.

Setara Institute, "Reports on Freedom of Religion and Belief 2007-2009" April 2, 2010, http:// www.setara-institute.org/en/content/reportfreedom-religion-and-belief-2007-2009 accessed January 20, 2012.

Surat Keputusan Dewan Pimpinan Majelis Ulama Indonesia tentang Pembentukan Komisikomisi," April 1996.

Toombs, Dennis, Power Why We want It and What to do with It, Promotheus Books, 2016. 
Ulum, Bahrul, Ulama dan Politik Nalar Politik Kebangsaan Majelis Ulama Indonesia (MUI) Yogyakata: Pustaka Pelajar, 2015.

Wodak, Ruth, and Michael Meyer, Methods Of Critical Discourse Analysis, London: Sage Publication, 2001.
Zulkifli, The Struggle of Shi'ism in Indonesia, Australia: E Press ANU, 2013. 